Kennesaw State University

DigitalCommons@Kennesaw State University

Faculty Publications

$2-2010$

\title{
The Location Decisions of Foreign Investors in China: Untangling the Effect of Wages Using a Control Function Approach
}

\author{
Xuepeng Liu \\ Kennesaw State University, xliu6@kennesaw.edu \\ Mary E. Lovely \\ Syracuse University \\ Jan Ondrich \\ Syracuse University
}

Follow this and additional works at: https://digitalcommons.kennesaw.edu/facpubs

Part of the Business Commons, Economics Commons, and the Statistical Models Commons

\section{Recommended Citation}

Liu, Xuepeng, Mary E. Lovely, and Jan Ondrich. "The Location Decisions of Foreign Investors in China: Untangling the Effect of Wages Using a Control Function Approach." Review of Economics and Statistics 92.1 (2010): 160-166.

This Article is brought to you for free and open access by DigitalCommons@Kennesaw State University. It has been accepted for inclusion in Faculty Publications by an authorized administrator of DigitalCommons@Kennesaw State University. For more information, please contact

digitalcommons@kennesaw.edu. 


\title{
NOTES
}

\section{THE LOCATION DECISIONS OF FOREIGN INVESTORS IN CHINA: UNTANGLING THE EFFECT OF WAGES USING A CONTROL FUNCTION APPROACH}

\author{
Xuepeng Liu, Mary E. Lovely, and Jan Ondrich
}

\begin{abstract}
There is almost no support for the proposition that capital is attracted to low wages from firm-level studies. We examine the location choices of 2,884 firms investing in China between 1993 and 1996 to offer two main contributions. First, we find that the location of labor-intensive activities is highly elastic to provincial wage differences. Generally, investors' wage sensitivity declines as the skill intensity of the industry increases. Second, we find that unobserved location-specific attributes exert a downward bias on estimated wage sensitivity. Using a control function approach, we estimate a downward bias of $50 \%$ to $90 \%$ in wage coefficients estimated with standard techniques.
\end{abstract}

\section{Introduction}

$\mathrm{C}$ OMPETITION for capital in labor-intensive activities with low entry barriers occurs largely among and within developing countries. This paper uses the location choices of foreign investors in China to estimate the response of capital to regional wage differentials. China is conducive to such a study because large capital inflows have been attracted in part by low wages and because there are substantial intracountry wage differences. During the period of substantial Chinese liberalization, 1992 to 1996, foreign-invested enterprises (FIEs) contributed $32 \%$ of fixed asset investment by all nonstate firms and over half of Chinese manufactured exports. ${ }^{1}$ During the same period, average real wages of Chinese industrial workers rose $7.2 \% .^{2}$ There was substantial variation in wage growth across provinces: real wages rose an average of $12.6 \%$ in Beijing but by only $0.7 \%$ in Hainan. Some observers claim that local governments prevented further wage gains in an effort to maintain flows of foreign capital. $^{3}$

Despite the importance of foreign capital to developing economies, our understanding of the extent to which investors are attracted to low-wage locations is surprisingly incomplete. Studies of aggregate investment flows provide consistent evidence that capital is attracted to low wages, but there is little support for this proposition from studies that use microdata. Such data are prized because aggregate data often are not rich enough to explore key questions such as how production technology influences firms' wage sensitivity.

This study offers two main contributions. First, using information on 2,884 manufacturing equity joint ventures (EJV) in China between 1993 and 1996, we find that low-wage locations are more attractive to unskilled-labor-intensive activities than to skill-intensive activities. These results suggest that rising wages most strongly influence inves-

Received for publication October 4, 2006. Revision accepted for publication April 9, 2008.

Liu: Kennesaw State University; Lovely: Syracuse University; Ondrich: Syracuse University.

We have benefited from discussions with Amil Petrin and Ken Train. We acknowledge helpful suggestions from Lee Branstetter, Judith Dean, Devashish Mitra, and seminar participants at the NBER China Working Group and the University of Nottingham. We are grateful to Gary Jefferson for providing Chinese industrial factor intensities.

${ }^{1}$ Investment percentage calculated by authors from Huang (2003, table 1.1). Export share taken from Huang (2003).

2 Percentage calculated by authors based on the wage data from Branstetter and Feenstra (2002).

${ }^{3}$ Ross and Chan (2002) forcefully articulate this view. Bhagwati (2004) provides a response. tors engaged in the least complex production activities. Second, we use a control function approach to conditional logit analysis discussed in Petrin and Train (2005) and estimate a downward bias of 50\% to $90 \%$ in the wage coefficients estimated with standard techniques. Overall, firms are more responsive to wages than previous estimates indicate.

\section{Wages, Firm Location Choice, and Omitted Variable Bias}

Because the literature on FDI flows is large, our review of previous studies of wages and firm location choice is necessarily targeted. From all studies using aggregate FDI flows, we discuss only results obtained in studies of investment into Chinese provinces. ${ }^{4}$ Among project-level studies, we examine results using data from foreign investment into the United States, the EU, and China. These regions receive the largest shares of foreign investment and permit study of location choice in the context of centralized labor market regulation.

Recent studies of the distribution of aggregate FDI flows among Chinese provinces or regions include Coughlin and Segev (2000), Wei et al., (1999), Cheng and Kwan (2000), Fung, lizaka, and Parker (2002), Gao (2002), and Fung, Iizaka, and Siu (2003). In all these studies, wages are found to be a statistically significant, negative determinant of the value of FDI flowing into a Chinese province or region. This result is robust to the choice of method and the inclusion of controls for skill level or skill availability. ${ }^{5}$ Thus, aggregate studies strongly support the view that firms seek locations with low wages, ceteris paribus.

Given the uniformity of results from aggregate flows, it is surprising that studies using microdata do not typically find wages to be a significant determinant of location choice. An insignificant wage coefficient has been estimated in studies using foreign plant locations in the United States (Ondrich \& Wasylenko, 1993; Head, Ries, \& Swenson, 1999; List \& Co, 2000; Keller \& Levinson, 2002), Europe (Devereux \& Griffith, 1998; Head \& Mayer, 2004), and China (Head \& Ries, 1996). Indeed, in some specifications, the estimated wage coefficient is positive. ${ }^{6}$ One possible explanation for these results may be that foreign investors invest in these locations for market access rather than cost reductions. However, within a common market, such as the United States or Europe, there remains a presumption that higher wages should influence the state or region that investors choose. Thus, the inability to estimate a significant, negative wage coefficient frustrates many researchers.

A common concern in location choice studies is the possibility that wages and unobserved location characteristics are not independent, so that standard econometric techniques that require exogenous covariates produce biased estimates. As exposited by Berry (1994) to explain low estimated price elasticities in differentiated product stud-

\footnotetext{
${ }^{4}$ We also note studies that use cross-country variation in wages, such as Wheeler and Mody (1992) and Wei (2000).

5 The only study that does not find a significant coefficient for wage, Gao (2002), divides the value of investment among fourteen source countries.

${ }^{6}$ A recent exception to this pattern is Amiti and Javorcik (2008), who relate changes in the number of foreign-invested firms in Chinese provinces to changes in the average wage.
} 
ies, sellers typically receive higher prices when their product has more desirable omitted characteristics. ${ }^{7}$ When this logic is applied to the FDI context, omitted location characteristics that influence productivity may lead to biased estimates of the wage sensitivity of investors. If the unobserved factors are otherwise mean independent of observed factors, there is unambiguously a downward bias in standard estimates: firms look less sensitive to the wage than they really are.

The need to control for unobserved location-specific attributes is widely recognized in studies using repeated cross-sections. One approach to spatially correlated errors is to estimate a nested logit model (e.g., Head \& Mayer, 2004). ${ }^{8}$ A second approach, which is used in both conditional logit estimation and count data methods, is to control for time-invariant unobserved spatial characteristics with fixed effects (e.g., Head \& Mayer, 2004; Keller \& Levinson, 2002). ${ }^{9}$ All of the studies listed include spatial fixed effects or use a nested logit procedure yet still find that the wage is not a significant determinant of location choice.

It is difficult to control for unobserved location-specific attributes for several reasons. First, there may be insufficient variation over time or too many empty cells to use fixed effects defined over the same geographic unit as the choice set. For this reason, Keller and Levinson (2002), in their study of foreign factory openings in U.S. states; Head and Mayer (2004), in their study of Japanese factory openings in regions within European countries; and Head and Ries (1996), in their study of FIE locations in Chinese provinces, use fixed effects defined over a geographic area larger than the unit of location choice. ${ }^{10}$

A second reason that it is difficult to control for unobserved location-specific attributes is that these unobservables may vary with time. This concern is particularly relevant in the Chinese case, where liberalization advanced at a varied pace, beginning in the coastal provinces but then pushing westward and increasing in speed, causing the productivity of local factors to change over time. For example, in 1992, the Chinese government significantly liberalized its FDI regime and decentralized approval from the central government to local governments (Huang, 2003). How quickly this regulatory change resulted in a liberalized investment environment varied from province to province. One way to capture such time-varying unobservables is to introduce time-province fixed effects to the conditional logit. This approach typically is problematic, however, as it would introduce more than 100 additional parameters to the estimation.

As an alternative, Berry, Levinsohn, and Pakes (1995) offer the product-market control approach, which has been widely used in estimating differentiated product models. It involves estimation of a set of controls that match observed to predicted market shares. Petrin and Train (2006) identify a number of advantages of this approach but note that unless sampling error in the market shares is minimal, this estimator is not consistent and is not asymptotically normal. Because the sampling error is unknown for the data we employ in this study, we choose not to use the product-market control method.

\footnotetext{
${ }^{7}$ Petrin and Train (2006) provide many examples from studies of differentiated product models, including the well-known study by Berry et al. (1995).

${ }^{8}$ Discussion of the application of these methods to modeling firm location decisions can be found in Ondrich and Wasylenko (1993).

${ }^{9}$ As Head et al. (1999) note, this provides a convenient way to capture common attributes. Many studies observe fewer than 1,000 investments, and there are few observations in many year-location cells. Consequently, parsimony is necessary.

${ }^{10}$ Keller and Levinson (2002) control for time-invariant state characteristics in their analysis of the value of foreign-owned gross property, plant, and equipment but are limited to the use of regional fixed effects in their analysis of planned new foreign-owned factory openings.
}

Another method for estimation of conditional logit models is proposed by Petrin (2005) and Petrin and Train (2005, 2006) based on control functions. A control function is a term added to an econometric specification to capture the effect of unobserved local characteristics, thereby breaking the correlation of the wage with the error term of the location-specific profit function. James Heckman $(1976,1979)$ pioneered the use of control functions to correct selectivity bias in normal linear regression models. The approach was used in the analysis of the Tobit model by Smith and Blundell (1986) and of the binary probit model by Rivers and Vuong (1988).

Typically the control function approach uses a two-step estimation. In the first step, OLS regression is used to estimate the variables that enter the control function. In our application, this first step requires the construction of an expected wage for each province in each year, with the residual used to specify a control function. In the second step, the likelihood function is maximized with the control function as additional explanatory variables. We find substantial differences between uncorrected estimates and those derived using the control function approach. ${ }^{11}$

\section{The Location Choice Model}

\section{A. The Profit Function}

We use a familiar model in which a firm chooses to locate where profits are maximized. ${ }^{12}$ A multinational firm seeks to invest somewhere in China. The firm produces with a generalized Cobb-Douglas technology, using variable inputs of labor, imported inputs, and a vector of locally provided services. Log profits for firm $i$ in province $j$ can be written as

$$
\ln \pi_{i j}=\alpha+\ln \left(1-\tau_{j}\right)-\theta_{L} \ln w_{j}-\theta_{m} \ln p_{m j}-\theta_{S} \ln p_{S j}-e_{i j},(1)
$$

where $\theta_{k}$ denotes a cost share, $\tau_{j}$ reflects the tax rate on foreign investment in province $j, w_{j}$ is the wage, $p_{m j}$ is the price of imported inputs, $p_{s j}$ is a price index for locally provided inputs, and $e_{i j}$ is an idiosyncratic cost shock. The intercept, $\alpha$, contains all terms that do not vary by province. Our empirical concern is with the estimation of the coefficient on the provincial wage, which depends on $\theta_{L}$, the labor cost share. It is clear from equation (1) that the effect on profits of a higher wage is larger for firms in labor-intensive industries.

\section{B. Benchmark Estimating Strategy}

Our basic estimating strategy is similar to conditional logit procedures in previous studies. We treat these conditional logit results as a benchmark for comparison to results obtained using the control function method. The profit function (1) yields a linear function for $\log$ profits with arguments given by the vector

$$
\mathbf{X}=\left[\ln (1-\tau), \ln w, \ln p_{m}, \ln p_{S}\right]
$$

Using (1), we obtain $\Pi=\mathbf{X} \beta+e$, where $\beta$ is the vector of parameters to be estimated. Our estimation strategy depends on the distribution of the unobserved idiosyncratic terms, $e_{i j}$. If these features are distributed independently according to an extreme value distribution,

\footnotetext{
${ }^{11}$ Petrin and Train (2006) find that estimated elasticities are similar across the control function and product-market approaches, but they both differ significantly from the uncorrected estimates.

${ }^{12}$ We condition on the decision to produce in China. We also use a static model of the investment decision, as is common in the literature.
} 
then the probability, $P_{k}$, that province $k$ is chosen, where $k$ is a member of choice set $J$, is given by

$$
P_{k}=\frac{\exp \left(x_{k} \beta\right)}{\sum_{j \in J} \exp \left(x_{j} \beta\right)}
$$

This conditional logit is well suited to the location choice problem since it exploits information on alternatives, accounts for matchspecific details, and allows multiple alternatives.

\section{Control Function Approach}

The possible endogeneity of the wage in estimation of (1) can be illustrated by specifying the error in the profit function as a twocomponent error: ${ }^{13}$

$$
e_{i j}=\beta_{\xi} \xi_{j}+\varepsilon_{i j},
$$

where $\xi_{j}$ is location specific, observed by workers and firms but not by the researcher. $\varepsilon_{i j}$ is an idiosyncratic error, assumed to be independent across firms and locations. Defining $\mathbf{X}_{j}$ as in (2) and letting $Z_{j}$ be a variable not in $\mathbf{X}_{j}$, under certain regularity conditions the log wage can be expressed as an implicit function of all factors taken as given at the time of the decision:

$$
\ln w_{j}=\ln w_{j}\left(\mathbf{X}_{j}, Z_{j}, \xi_{j}\right) .
$$

Because wages will be higher in locations with more desirable omitted characteristics, $e_{i j}$ and $\ln w_{j}$ will be correlated even after conditioning on $\mathbf{X}_{j}$, violating the weak-exogeneity requirement for conditional logit covariates and leading to inconsistent parameter estimates.

Petrin and Train $(2005,2006)$ illustrate how a control function can be used to test for and correct the omitted variables problem. The method proceeds in two steps. The first step is a linear regression of $\log$ wages $\left(\ln w_{j}\right)$ on exogenous variables $\mathbf{X}_{j}$ and $Z_{j}$ using provinciallevel data across years. We use this regression to construct the expected wage for each province in each year. The residual is used to estimate the control function, $f\left(\mu_{j}, \lambda\right)$, where $\mu_{j}$ is the disturbance from the first-stage regression and $\lambda$ is a vector of estimated parameters. The profit function for firm $i$ locating in province $j$ can now be written as

$$
\ln \pi_{i j}=\alpha+\mathbf{X}_{i j} \beta+f\left(\mu_{j}, \lambda\right)+\left(\beta_{\xi} \xi_{j}-f\left(\mu_{j}, \lambda\right)\right)+\varepsilon_{i j} .
$$

The new error, $\eta_{i j}=\beta_{\xi} \xi_{j}-f\left(\mu_{j}, \lambda\right)+\varepsilon_{i j}$, includes the difference between the actual province-specific error $\beta_{\xi} \xi_{j}$ and the control function, plus the idiosyncratic error.

Therefore, we assume that at location $j$, the log wage, $\ln w_{j}$, can be expressed as

$$
\ln w_{j}=E\left(\ln w_{j} \mid \mathbf{X}_{j}, Z_{j}\right)+\mu_{j}\left(\xi_{j}\right),
$$

where $\mu_{j}\left(\xi_{j}\right)$ is one-to-one in $\xi_{j}$. Including $f\left(\mu_{j}, \lambda\right)$ in the conditional logit specification holds constant the variation in the error term of the location-specific profit function that is not independent of the wage. The equation for $\ln w_{j}$ above implies that $\hat{\mu}_{j}$ can be constructed as the residual from a first-stage regression of $\ln w_{j}$ on $\mathbf{X}_{j}$ and $Z_{j}$. Because the residual $\hat{\mu}_{j}$ replaces the disturbance $\mu_{j}$ in the control function when estimation is performed, the usual standard errors are incorrect.

\footnotetext{
${ }^{13}$ This discussion adapts the discussion of consumers' choice among differentiated products in Petrin and Train (2006) to the location choice context.
}

As described in the appendix, we use bootstrapping methods to correct the standard errors.

This approach requires a regressor for the first-stage wage regression that is correlated with the wage paid by EJVs but uncorrelated with foreign firms' location choices, conditional on other covariates. Identifying a suitable choice requires characterization of the wagesetting process in China. As discussed in Chan (2003), although local governments set minimum wages, private firms are otherwise free to set wage levels. Given this, our first-stage regression is a reducedform wage equation with controls for labor supply (e.g., the share of the labor force with secondary education) and for labor demand (e.g., the rate at which output of state-owned enterprises is falling).

We use the log of the average industrial wage paid by SOEs as $Z_{j}$ in our first-stage regression. Both state-owned enterprises (SOEs) and EJVs hire labor that is relatively skilled. Our choice is valid if private sector wages are influenced by some provincial characteristics that drive multifactor productivity, while SOE wages are not. We rely on the nature of the SOE wage-setting process and SOE productivitywage gaps to argue for the independence of SOE wages from unobserved factors that drive foreign-firm productivity. In China, SOE wages prior to 1996 were largely determined by the central government, despite several rounds of wage reforms. Starting in 1985, the Ministry of Labor (MOL) provided some profit-oriented incentives to SOEs, but to a very limited extent. ${ }^{14}$ Deeper reforms of China's SOE wage structure were not implemented until the Ninth Five Year Plan (1996-2000). Therefore, during the time frame of our sample, SOE wages were largely set by central government guidelines and were largely unresponsive to changes in private sector productivity. ${ }^{15}$

\section{Data Description and Sources}

The sample of equity joint venture investments was constructed by Dean, Lovely, and Wang (2009), who provide details of the construction. The sample contains EJVs undertaken between 1993 and 1996 using project descriptions available from the Chinese Ministry of Foreign Trade and Economic Cooperation (MOFTEC). ${ }^{16}$ We add regional fixed effects to capture regional correlation in supply and demand shocks. Complete descriptions and sources for all variables are provided in table 1 .

The wage measure is the average annual wage paid by private and foreign enterprises in the province, drawn from Branstetter and Feenstra (2002), who also provide the average annual wage paid by SOEs, which we use in the first-stage wage regression. Average wages do not control for provincial variation in labor quality, so we include the share of the provincial labor force that has completed senior secondary school or above.

${ }^{14}$ For example, as Yueh (2004) showed, the State Council in 1992 permitted SOEs to set wages within the confines of a budget established by the government. However, if a wage bill exceeded the MOL standard, the enterprise paid a wage adjustment tax of $33 \%$. Alternatively, the enterprise could propose a wage budget and then submit it for approval.

${ }^{15}$ Evidence from SOE productivity-wage gaps also supports the view that SOE wages do not reflect local attributes that influence foreign firms' productivity. Parker (1995) finds that "in 1992, state industrial wages were 43 percent higher than those available in urban collectives, and only 22 percent below those of the other ownership forms; these workers in other ownership forms, however, were 130 percent (in 1990 prices) to 200 percent (in 1980 prices) more productive than those under stateownership."

${ }^{16}$ Equity joint ventures are limited liability companies incorporated in China, in which foreign and Mainland Chinese investors hold equity. For further details, see Fung (1997). 
Table 1.-Data Definitions and Sources

\begin{tabular}{|c|c|c|c|c|}
\hline Variable & Definition & Source & Mean $^{\mathrm{a}}$ & s.d. ${ }^{\mathrm{a}}$ \\
\hline EJV project & & Almanac of China's Foreign Economic Relations & & \\
\hline Location & Province & and Trade, various years, Dean, Lovely, and & & \\
\hline Industry & 3-digit ISIC Rev. 2 classification & Wang (2009) & & \\
\hline SOE wage & $\begin{array}{l}\text { Average annual wage for industrial workers in state- } \\
\text { owned enterprises, in } 1990 \text { yuan }\end{array}$ & $\begin{array}{l}\text { Branstetter and Feenstra (2002), from China } \\
\text { Statistical Yearbook, various years }\end{array}$ & 2,837 & 656 \\
\hline Private wage & $\begin{array}{l}\text { Average annual wage for industrial workers in other } \\
\text { enterprises (private, foreign), in } 1990 \text { yuan }\end{array}$ & $\begin{array}{l}\text { Branstetter and Feenstra (2002), from China } \\
\text { Statistical Yearbook, various years }\end{array}$ & 3,254 & 951 \\
\hline Agglomeration & $\begin{array}{l}\text { Cumulative value of real contracted FDI, from } 1983 \\
\text { until } t-1 \text {, in millions of } 1980 \text { U.S. dollars }\end{array}$ & Coughlin and Segev (2000) & 1,536 & 3,023 \\
\hline Local firms & $\begin{array}{l}\text { SOE and collective enterprises at the township level } \\
\text { and above }\end{array}$ & $\begin{array}{l}\text { China Statistical Yearbook, various years, Dean, } \\
\text { Lovely, and Wang (2009) }\end{array}$ & 16,061 & 10,871 \\
\hline Population & Province population, in millions & China Statistical Yearbook, various years & 41 & 27 \\
\hline Skilled labor ratio & $\begin{array}{l}\text { Share of population who have a senior secondary } \\
\text { school education level or above, in percentage } \\
\text { points }\end{array}$ & $\begin{array}{l}\text { China Statistical Yearbook, various years and } \\
\text { calculations by authors }\end{array}$ & 12.08 & 6.19 \\
\hline Telephone density & $\begin{array}{l}\text { Number of urban telephone subscribers per million } \\
\text { persons }\end{array}$ & China Statistical Yearbook, various years & 29,266 & 29,382 \\
\hline Road density & Road $(\mathrm{km})$ per thousand $\mathrm{km}^{2}$ of land area & China Statistical Yearbook, various years & 248 & 147 \\
\hline Private market size & $\begin{array}{l}\text { Real provincial GDP } \times(1-\text { SOE share }) \text {, where SOE } \\
\text { share is the production share of SOEs; GDP is } \\
\text { value in billions of } 1990 \text { yuan }\end{array}$ & $\begin{array}{l}\text { China Statistical Yearbook, various years, and } \\
\text { calculations by authors }\end{array}$ & 57 & 56 \\
\hline $\begin{array}{c}\text { Change in state } \\
\text { ownership }\end{array}$ & $\begin{array}{l}\text { Difference in shares of industrial output from SOEs in } \\
\text { year } t \text { and } t-1\end{array}$ & $\begin{array}{l}\text { China Statistical Yearbook, various years, Dean, } \\
\text { Lovely, and Wang (2009) }\end{array}$ & -0.04 & 0.05 \\
\hline SEZ or OCC & $\begin{array}{l}\text { Dummy variable for a province with SEZ or open } \\
\text { coastal city }\end{array}$ & Dean, Lovely, and Wang (2009) & 0.43 & 0.50 \\
\hline Capital stock & Capital stock, in 100 million 1978 yuan & Kui-Wai Li (2003) & 1,784 & 1,610 \\
\hline S\&T Intensity & $\begin{array}{l}\text { Science and Technology expenditure as share of value- } \\
\text { added } \times 10 \text {, by ISIC } 3 \text {-digit classification } \\
\text { (concordance by authors) }\end{array}$ & $\begin{array}{l}\text { NBS Large and Medium Enterprise Survey, } \\
\text { 1995, calculated by Gary Jefferson }\end{array}$ & 0.50 & 0.30 \\
\hline
\end{tabular}

Descriptive statistics for provincial characteristics calculated from pooled data for 1993-1996 (excluding Tibet and Gansu).

We do not have direct measures of the cost of imported inputs $\left(p_{m}\right)$ or the corporate tax rate $(\tau)$. To control for provincial variation in these factors, we include an incentive dummy that takes a value of 1 if there is a special economic zone (SEZ) or open coastal city (OCC) in the province. We also include two measures of provincial infrastructure: length of roads adjusted for provincial size and number of urban telephone subscribers relative to population.

To account for provincial variation in the price of local intermediate services $\left(p_{s}\right)$, we follow Head and Ries (1996) and include two determinants of this price: the number of foreign firms and the number of potential local suppliers. ${ }^{17}$ The number of foreign firms is measured as the real value of cumulative FDI, which we refer to as agglomeration, for the period 1983 to the year before the project is undertaken. Availability of potential suppliers of intermediate goods is measured by the number of domestic enterprises at the township level and above. To control for local market demand, we include population size and provincial private GDP and its square. Sales may also be affected by the extent to which a province is liberalizing, so we include the change in the share of industrial output produced by SOEs.

\section{Results}

Theory suggests that wages have a larger effect on profits in labor-intensive industries, and so we expect these industries to be more responsive to provincial variations in labor costs when choosing an investment location. To allow for this differential response, we

${ }^{17}$ Head and Ries (1996) develop a model of self-reinforcing FDI in which the equilibrium number of intermediate suppliers depends on the final-good price, the number of foreign firms to which domestic suppliers may sell and the number of domestic firms that may undertake the costly upgrading necessary to serve foreign firms. characterize industries using Chinese industrial data on skill intensity, expecting a more elastic response in industries that are less skill intensive. Each industry's skill intensity is based on data from the Chinese National Bureau of Statistics' Large-and-Medium Enterprise (LME) Survey; it is calculated as total science and technology expenditures, including personnel, as a share of value added. ${ }^{18}$ We predict that the estimated coefficient for the interaction of the private wage and skill intensity will be positive: wage sensitivity should be lower for more skill-intensive ventures.

\section{A. Standard Estimation Results}

The first two panels of table 2 report results estimated using standard techniques, without the inclusion of a control function. All covariates are lagged one year. The overall fit of the equation is comparable to other studies using similar procedures (e.g., Head \& Ries, 1996; Head \& Mayer, 2004). All coefficients have their expected signs, except provincial capital stock in the model without regional fixed effects, and all are statistically significant.

For both specifications, we estimate a negative and highly significant coefficient for the private wage. In comparing results in the first and second models, we see that the estimated value of the wage coefficient drops by $35 \%$ when regional fixed effects are included. Evidently controlling for time-invariant regional characteristics that may be correlated with the wage reduces the estimated attraction of low wages.

${ }^{18}$ The LME survey is the most comprehensive firm-level data set available for Chinese industrial firms. Access to the LME is restricted. Results obtained using U.S. data to characterize skill intensity produce similar results. 
THE REVIEW OF ECONOMICS AND STATISTICS

TABle 2.-Conditional Logit Analysis of EJV Provincial Location

\begin{tabular}{|c|c|c|c|c|c|c|c|c|}
\hline & \multicolumn{4}{|c|}{ Without Control Function } & \multicolumn{4}{|c|}{ With Control Function } \\
\hline & Coefficient & s.e. & Coefficient & $\overline{\text { s.e. }}$ & Coefficient & s.e. & Coefficient & s.e. \\
\hline Log private wage & $-2.40 * * *$ & 0.24 & $-1.55 * * *$ & 0.25 & $-3.75 * * *$ & 0.50 & $-2.93 * * *$ & 0.57 \\
\hline Log wage $\times$ S\&T intensity & $1.04 * * *$ & 0.26 & $1.06^{* * *}$ & 0.26 & $1.25 * * *$ & 0.30 & $1.33 * * *$ & 0.30 \\
\hline Log agglomeration & $0.22 * * *$ & 0.05 & $0.33 * * *$ & 0.05 & $0.35 * * *$ & 0.07 & $0.48 * * *$ & 0.08 \\
\hline Log local firms & $0.82 * * *$ & 0.11 & $1.04 * * *$ & 0.12 & $0.67 * * *$ & 0.14 & $0.95 * * *$ & 0.13 \\
\hline Log population & $0.99 * * *$ & 0.15 & $1.97 * * *$ & 0.18 & $0.79 * * *$ & 0.18 & $1.80 * * *$ & 0.22 \\
\hline Skilled labor ratio & $0.09 * * *$ & 0.01 & $0.09 * * *$ & 0.01 & $0.09 * * *$ & 0.01 & $0.07 * * *$ & 0.01 \\
\hline Log telephone density & $0.53 * * *$ & 0.10 & $0.49 * * *$ & 0.13 & $0.61 * * *$ & 0.12 & $0.69 * * *$ & 0.17 \\
\hline Log road density & $0.41 * * *$ & 0.08 & 0.10 & 0.10 & $0.50 * * *$ & 0.09 & 0.11 & 0.11 \\
\hline Log private market size & $-1.85^{* * *}$ & 0.24 & $-3.13 * * *$ & 0.27 & $-1.80 * * *$ & 0.26 & $-3.12 * * *$ & 0.30 \\
\hline \multicolumn{9}{|l|}{ Squared log private market } \\
\hline size & $0.21 * * *$ & 0.02 & $0.16 * * *$ & 0.03 & $0.22 * * *$ & 0.02 & $0.16 * * *$ & 0.03 \\
\hline Change in state ownership & $-2.91 * * *$ & 0.78 & $-6.06 * * *$ & 0.84 & $-3.66 * * *$ & 1.12 & $-6.65^{* * *}$ & 1.12 \\
\hline SEZ or OCC & $0.86 * * *$ & 0.10 & $1.05 * * *$ & 0.17 & $0.72 * * *$ & 0.12 & $0.88 * * *$ & 0.19 \\
\hline Log capital stock & $-0.15^{* * *}$ & 0.06 & $0.41 * * *$ & 0.14 & $-0.24 * * *$ & 0.08 & $0.45 * * *$ & 0.15 \\
\hline \multicolumn{9}{|l|}{ Regional fixed effects } \\
\hline Central & & & $1.42 * * *$ & 0.17 & & & $1.41 * * *$ & 0.17 \\
\hline Coastal & & & $2.01 * * *$ & 0.20 & & & $1.96 * * *$ & 0.22 \\
\hline Northeast & & & $0.69 * * *$ & 0.20 & & & 0.38 & 0.25 \\
\hline Northwest & & & 0.06 & 0.24 & & & -0.10 & 0.27 \\
\hline Residual & & & & & $2.82 * * *$ & 0.85 & $2.79 * * *$ & 0.91 \\
\hline Residual $\times$ S\&T intensity & & & & & -1.18 & 0.95 & -1.62 & 0.92 \\
\hline Number of observations & \multicolumn{2}{|l|}{2,884} & \multicolumn{2}{|l|}{2,884} & \multicolumn{2}{|c|}{2,884} & \multicolumn{2}{|c|}{2,884} \\
\hline LR test & \multicolumn{2}{|l|}{3,358} & \multicolumn{2}{|l|}{3,522} & \multicolumn{2}{|c|}{3,384} & \multicolumn{2}{|c|}{3,542} \\
\hline Log likelihood & \multicolumn{2}{|l|}{$-7,931$} & \multicolumn{2}{|l|}{$-7,849$} & \multicolumn{2}{|c|}{$-7,918$} & \multicolumn{2}{|c|}{$-7,839$} \\
\hline Pseudo- $R^{2}$ & \multicolumn{2}{|l|}{0.175} & \multicolumn{2}{|l|}{0.183} & \multicolumn{2}{|c|}{0.176} & \multicolumn{2}{|c|}{0.184} \\
\hline Schwarz criterion & \multirow{3}{*}{\multicolumn{2}{|c|}{$-7,983$}} & \multirow{3}{*}{\multicolumn{2}{|c|}{$-7,917$}} & \multicolumn{2}{|c|}{$-7,978$} & \multicolumn{2}{|c|}{$-7,915$} \\
\hline CF Wald statistic & & & & & \multicolumn{2}{|c|}{$11.74 * * *$} & \multicolumn{2}{|c|}{$9.38 * * *$} \\
\hline ( $p$-value) & & & & & \multicolumn{2}{|c|}{$(0.003)$} & \multicolumn{2}{|c|}{$(0.009)$} \\
\hline
\end{tabular}

Notes: *significant at $10 \% ; * *$ significant at $5 \% ; * * *$ significant at $1 \%$. Variables are lagged by one year. Gansu and Tibet excluded.

In both models, the interaction of wage and industrial skill intensity is positive and highly significant, as expected. The estimated coefficient for this interaction is very similar across the two models. Because the maximum value of the skill intensity measure is 1.13 , either model suggests that higher wages make a province a less attractive site for investment, ceteris paribus, for every industry. However, the reduction in the wage coefficient caused by inclusion of regional fixed effects, as in standard estimating strategy, leads to a wage coefficient for firms with the mean level of skill intensity (0.54) of -0.98 .

Coefficients for other covariates also change in value when regional fixed effects are added, but only the capital stock coefficient changes sign. The regional coefficients indicate that EJVs are more likely to locate in any region other than the Southwest, although the difference is not significant for the Northwest region. As expected, these coefficients are largest for the central and coastal zones, which have the longest history of market liberalization.

\section{B. Control Function Results}

The third and fourth models in table 2 provide results estimated using the control function approach. Specifically, we include the residual from the first-stage wage regression and the interaction of this residual and industry skill intensity in the conditional logit estimation. The third model omits regional fixed effects, while the fourth model includes them. The reported standard errors (as well as variance matrices used in the testing of joint hypotheses) are corrected using a bootstrapping technique described in the appendix. The first-stage regression explains $86 \%$ of the variation in the private wage, and the coefficient of the log of the SOE wage is highly significant, with a $t$-statistic of 8.76 . Adding the $\log$ of the SOE wage to the first stage explains an additional $5 \%$ of the variation in private wages. ${ }^{19}$

When the control function is added, the wage coefficient remains negative and highly significant. However, it increases in absolute value, providing an estimate of the downward bias in the standard method. Comparing the first and third equations, those estimated without regional effects, we find that the coefficient of -3.75 estimated with the control function is $56 \%$ larger than the coefficient of -2.40 estimated without the control function. Again, the coefficient for the interaction of wage and industry skill intensity is highly significant. This estimated coefficient is only slightly affected by inclusion of the control function. The estimates obtained from the third model indicate a wage coefficient of -3.10 for firms with average skill intensity.

When we include regional fixed effects as well as the control function, the estimated coefficient is reduced somewhat, from -3.75 to -2.93 but remains larger than either model estimated without the control function. Indeed, in comparison to the standard estimating strategy using regional fixed effects, the wage coefficient is $89 \%$ larger. Again we find that skill intensity significantly influences firms' wage sensitivity. The wage response for all firms is negative, and the estimated wage coefficient for firms with average skill intensity is -2.21. Coefficient estimates on other variables are similar to those estimated in the second model, with regional fixed effects only.

We use theoretical concerns, knowledge of the Chinese context, and diagnostic statistics to set criteria for choosing a preferred spec-

\footnotetext{
${ }^{19}$ First-stage wage regression results are available from the authors by request. We include regional fixed effects in the wage regression when they are included in the conditional logit.
} 
ification among these four models. From theory, we expect that unobserved location advantages will be reflected in equilibrium wages, leading us to suspect that omitted variables may be present in the standard estimating strategy. From the Chinese context, we understand that liberalization proceeded rapidly but not uniformly between 1993 and 1996, implying that the investment environment in all provinces evolved during the period.

For diagnostics, Petrin and Train (2006) suggest the use of a joint significance test for the control function coefficients as a test of the exogeneity of the log wage. In the two models estimated with the control function, the values of the control function (CF) Wald statistic reject exogeneity. We use the Schwarz criterion to assess which of the four models performs best. The Schwarz criterion selects a model from a set of proposed models of different dimensions by finding its Bayes solution and evaluating the first terms of the asymptotic expansion, which do not depend on the prior distribution. It penalizes the log likelihood of each model by subtracting half of the product of the number of parameters and log sample size. Heckman and Walker (1987) include the Schwarz criterion in their set of criteria to choose among competing duration models. Mills and Prasad (1992) find that the Schwarz criterion consistently outperforms other model selection criteria in a Monte Carlo analysis. In our case, the Schwarz criterion favors the model in which both the control function and regional fixed effects are included.

Based on these criteria, we use the model that includes the control function and regional fixed effects to illustrate the varying response of industries to wage differentials. For this purpose, we calculate the elasticity with respect to the wage of the probability that a particular province is chosen by a particular industry. This elasticity measure is directly relevant to the policy concerns of local officials, who are interested in the extent to which wage growth reduces the likelihood that their province will be selected. As these elasticity calculations depend on provincial characteristics, we illustrate our results using Jiangsu, the province that received the largest number of projects in our sample. We also calculate the associated standard error for this estimate, using the delta method, and we test whether the elasticity estimate is significantly different from unity.

Our estimates suggest that location choices of labor-intensive industries are quite elastic with respect to wage increases. Foreigninvested enterprises account for a large share of export production in these industries. The least skill-intensive industry, wood products, has a skill measure of 0.17 and an estimated own-wage elasticity in Jiangsu of -2.15 (standard error of 0.32 ). The two industries that accounted for the largest shares of Chinese exports in 1995 are also highly sensitive to local wage differences: the estimated own-wage elasticity for the textile industry is $-1.77(0.38)$ and for apparel, -2.12 (0.31). Footwear, another industry that accounts for a large share of exports, also has a large own-wage elasticity: $-2.11(0.31)$. Each of these elasticities is significantly different from unity. In comparison, the most skill-intensive industry, the manufacture of professional, scientific, and controlling equipment, received little foreign investment during this time period. This industry has a skill measure of 1.13 and an estimated own-wage elasticity of -1.13 (0.25). We cannot reject the hypothesis of unitary elasticity for this industry or for other highly skill-intensive industries.

\section{Conclusion}

Previous microdata studies of firm location choice provide little support for the standard theoretical prediction that firms are sensitive to local wages in choosing a location for foreign investment. Using data from equity-joint-venture projects in China, we explore the possibility that unobserved location-specific attributes exert a downward bias on estimates of investors' response to wage differentials. We introduce to the location-choice context a control function approach applied by Petrin and Train $(2005,2006)$. Our results indicate that standard conditional logit techniques underestimate the sensitivity of investors to local wages and that coefficient estimates using the control function are $50 \%$ to $90 \%$ larger in absolute value.

A second contribution of the paper is new evidence on the nature of firms' attraction to low wages. Firms' responses to wages vary systematically with the skill intensity of production. Investors in the least skill-intensive industries exhibit the largest wage sensitivity in choosing a host. Textiles, apparel, and footwear constituted large shares of China's overall manufacturing exports in 1995 and exhibited highly elastic responses to local wage differences. In recent years, exports of more skill-intensive products, such as office and computing machinery and communications equipment, have grown rapidly. Our results indicate that investors in skill-intensive industries are less sensitive to local wages. Together these results suggest that wage pressures on local hosts change as the development process matures.

\section{REFERENCES}

Amiti, Mary, and Beata Smarzynska Javorcki, "Trade Costs and the Location of Foreign Firms in China," Journal of Development Economics 85 (2008), 129-149.

Berry, Steven, "Estimating Discrete Choice Models of Product Differentiation," RAND Journal of Economics 25 (1994), 242-262.

Berry, Steven, James Levinsohn, and Ariel Pakes, "Automobile Prices in Market Equilibrium," Econometrica 63 (1995), 841-890.

Bhagwati, Jagdish, In Defense of Globalization (New York: Oxford University Press, 2004).

Branstetter, Lee, and Robert C. Feenstra, "Trade and Foreign Direct Investment in China: A Political Economy Approach," Journal of International Economics 57 (2002), 335-358.

Chan, Anita, "A Race to the Bottom," China Perspective 46 (2003), $41-49$.

Cheng, Leonard K., and Yum K. Kwan, "What Are the Determinants of the Location of Foreign Direct Investment? The Chinese Experience," Journal of International Economics 51 (2000), 370-400.

Coughlin, Cletus C., and Eran Segev, "Foreign Direct Investment in China: A Spatial Econometric Study,” World Economy 23 (2000), $1-23$.

Dean, Judith M., Mary E. Lovely, and Hua Wang, “Are Foreign Investors Attracted to Weak Environmental Regulations? Evaluating the Evidence from China," Journal of Development Economics 90 (2009), 1-13.

Devereux, Michael, and Rachel Griffith, "Taxes and the Location of Production: Evidence from a Panel of U.S. Multinationals," Journal of Public Economics 68 (1998), 1-23.

Fung, Kwok-Chiu, Trade and Investment: Mainland China, Hong Kong, and Taiwan (Hong Kong: City University of Hong Kong Press, 1997).

Fung, Kwok-Chiu, Hitomi Iizaka, and Stephen Parker, "Determinants of U.S. and Japanese Direct Investment in China," Journal of Comparative Economics 30 (2002), 567-578.

Fung, Kwok-Chiu, Hitomi Iizaka, and Alan Siu, "Japanese Direct Investment in China," China Economic Review 14 (2003), 304-315.

Gao, Ting, "Labor Quality and the Location of Foreign Direct Investment: Evidence from FDI in China by Investing Country," University of Missouri mimeograph (2002).

Head, Keith, and Thierry Mayer, "Market Potential and the Location of Japanese Investment in the European Union," this REVIEW 86 (2004), 959-972.

Head, Keith, and John Ries, "Inter-City Competition for Foreign Investment: Static and Dynamic Effects of China's Incentive Areas," Journal of Urban Economics 40 (1996), 38-60.

Head, Keith, John Ries, and Deborah Swenson, "Attracting Foreign Manufacturing: Investment Promotion and Agglomeration," Regional Science and Urban Economics 29 (1999), 197-218. 
Heckman, James, "The Common Structure of Statistical Models of Truncation, Sample Selection and Limited Dependent Variables and a Simple Estimator for Such Models," Annals of Economic and Social Measurement 5 (1976), 475-492.

"Sample Selection Bias as a Specification Error," Econometrica 47 (1979), 153-162.

Heckman, James J., and James R. Walker, "Using Goodness of Fit and Other Criteria to Choose among Competing Duration Models: A Case Study of Hutterite Data," Sociological Methodology 17 (1987), 247-307.

Henley, John, Colin Kirkpatrick, and Georgina Wilde, "Foreign Direct Investment in China: Recent Trends and Current Policy Issues," World Economy 22 (1999), 223-243.

Huang, Yasheng, Selling China: Foreign Investment during the Reform Era (Cambridge: Cambridge University Press, 2003).

Karaca-Mandic, Pinar, and Kenneth Train, "Standard Error Correction in Two-Stage Estimation with Nested Samples," Econometrics Journal 62 (2003), 401-407.

Keller, Wolfgang, and Arik Levinson, "Pollution Abatement Costs and Foreign Direct Investment Inflows to the United States," this REVIEW 84 (2002), 691-703.

Li, Kui-Wai, "China's Capital and Productivity Measurement Using Financial Resources," Economic Growth Center, Yale University working paper no. 851 (2003).

List, John A., and Catherine Y. Co, "The Effects of Environmental Regulations on Foreign Direct Investment," Journal of Environmental Economics and Management 40 (2000), 1-20.

Mills, Jeffrey, and Kislaya Prasad, "A Comparison of Model Selection Criteria," Econometric Reviews 11 (1992), 201-234.

Ondrich, Jan, and Michael Wasylenko, Foreign Direct Investment in the United States (Kalamazoo, MI: W. E. Upjohn Institute for Employment Research, 1993).

Parker, Elliott, "Prospects for the State-Owned Enterprise in China's Socialist Market Economy," Asian Perspective 19 (1995), 7-35.

Petrin, Amil, "The Use of Control Functions to Identify Demand when Errors are Non-Additive," GSB working paper and University of Chicago mimeograph (2005).

Petrin, Amil, and Kenneth Train, "Tests for Omitted Attributes in Differentiated Product Models," University of Minnesota mimeograph (2005). "Control Function Corrections for Omitted Attributes in Differentiated Product Models," University of Minnesota mimeograph (2006).

Rivers, Douglas, and Quang H. Vuong, "Limited Information Estimators and Exogeneity Tests for Simultaneous Probit Models," Journal of Econometrics 39 (1988), 347-366.

Ross, Robert, J. S., and Anita Chan, "From North-South to South-South: The True Face of Global Competition," Foreign Affairs 81 (2002), 8-13.

Smith, Richard J., and Richard W. Blundell, "An Exogeneity Test for a Simultaneous Equation Tobit Model with an Application to Labor Supply," Econometrica 54 (1986), 679-686.
Wei, Shang-Jin, "How Taxing Is Corruption on International Investors?" this REVIEW 82 (2000), 1-11.

Wei, Yingqi, Xiaming Liu, David Parker, and Kirit Vaidya, "The Regional Distribution of Foreign Direct Investment in China," Regional Studies 33 (1999), 857-867.

Wheeler, David, and Ashoka Mody, "International Investment Location Decisions: The Case of U.S. Firms," Journal of International Economics 33 (1992), 57-76.

Yueh, Linda Y., "Wage Reforms in China during the 1990s," Asian Economic Journal 18 (2004), 149-164.

\section{APPENDIX}

\section{First-Stage Results and Bootstrapping Procedures}

A maintained primitive of the control function approach is that wages are additively separable in the observed $\left(\mathbf{X}_{j}\right.$ and $\left.Z_{j}\right)$ and the unobserved factors $\left(\xi_{j}\right)$; that is, the unobserved factors are mean independent of the observed factors. This assumption implies uncorrelatedness of unobservables and covariates. It enables use of linear regression in the first stage and ensures the consistent estimation of the residual from the first stage. In the first stage, we regress log private wage on all variables in the conditional logit and log SOE wage, as described in the text.

When a control function that includes predicted values is added to the estimation, the coefficients are consistent, but the standard errors are incorrect. Petrin and Train (2006) use bootstrapping to correct standard errors in their applications. In the first stage, we bootstrap a wage sample and regress the private wage on the exogenous variables and the log of the SOE wage for the years 1990 to $1996 .{ }^{20}$ The control function in the second stage is a function of the first-stage residual and the interactions of the residual with industrial skill intensity. We run the conditional logit with this control function and repeat this process 100 times. The variances of these bootstrapped coefficients in the second stage are added to the traditional variance estimates from the conditional logit regression with the control function. ${ }^{21}$ We experiment with different orders of the polynomial of the residuals to specify the control function. Typically higher orders are insignificant and have only a small effect; hence they are not included in our regressions.

${ }^{20}$ We do not use years after 1996 in the first stage to avoid possible structural changes in wage structure after 1996 due to SOE reforms. We also do not use years before 1990 for similar concerns. Years after 1989 and before 1993 are kept to increase the sample size and the reliability of bootstrapping. However, the direction and magnitude of bias are consistent when we experiment with different years in the first stage.

${ }^{21}$ Karaca-Mandic and Train (2003) propose alternative standard error correction procedures, but find results very similar to bootstrapping.

\title{
TRADING ON TIME
}

\author{
Simeon Djankov, Caroline Freund, and Cong S. Pham*
}

\begin{abstract}
We determine how time delays affect trade, using newly collected data on the days it takes to move standard cargo from the factory gate to the ship in 98 countries. We estimate a difference gravity equation and find that each additional day that a product is delayed prior to being shipped reduces trade by more than $1 \%$. Put differently, each day is equivalent to a country

Received for publication December 18, 2006. Revision accepted for publication May 16, 2008.

* Djankov: Ministry of Finance, Bulgaria; Freund: Research Department, World Bank; Pham: School of Accounting, Economics and Finance, Deakin University.
\end{abstract}

distancing itself from its trade partners by about $70 \mathrm{~km}$ on average. We also find that delays have a relatively greater impact on exports of time-sensitive goods, such as perishable agricultural products.

We thank Mary Amiti, Andrew Bernard, James Harrigan, Bernard Hoekman, Amit Khandelwal, Stephen Redding, Dani Rodrik, Alan Winters, two anonymous referees, and seminar participants at Dartmouth College, the Georgia Institute of Technology, the New York Federal Reserve Bank, and the World Bank for comments, and Marcelo Lu and Darshini Manraj for collecting the data. 